\title{
A FÖLDRAJZ ÉS A TÖRTÉNELEM TANTÁRGYAK KAPCSOLATA A KÖZNEVELÉSI RENDSZER 7-10. ÉVFOLYAMAIN
}

The connection between the subjects geography and history in grades $7-10$ of the Hungarian education system

\section{SERES ZOLTÁN}

Eötvös Loránd Tudományegyetem TTK FFI Földrajz szakmódszertani csoport seres.zoltan@ttk.elte.hu

\section{ABSTRACT}

This paper reviews the connection between geography and history within the education system of Hungary and uses documentary analysis to examine the 2020 curricula of the two subjects, with a particular focus on the frame curricula. Based on these documents, it can be concluded that - e. g. due to the curricular structure and the reduction of the number of classes - it is rather difficult to synthesise and integrate the two subjects, however, not impossible. The study presents the links between the two subjects in three major groups and makes methodological recommendations for teachers.

Keywords: geography, history, frame curriculum, integrated curriculum, synthesize

\section{BEVEZETÉS}

„A két tárgy kapcsolata a közoktatásban szoros, bár lehetne még szorosabb is, hiszen számtalan közös feladatunk van az állampolgári nevelésben és a gazdasági ismeretek terén is, a történelem jelentös rokontudománya a társadalomföldrajz. Sok történelemtanár olvasónk szakpárja a földrajz..." e sorok a 2017-ben indult GeoMetodika földrajz szakmódszertani folyóirat indulásának apropóján jelentek meg szerkesztőségi állásfoglalásként a Történelemtanítás című online történelemdidaktikai folyóiratban. Földrajztörténelem szakos középiskolai tanárként magam is azt gondolom, hogy a két tantárgy kapcsolata valóban lehetne szorosabb. A 2020-ban módosított Nemzeti alaptanterv és a hozzá készült általános iskolai és gimnáziumi kerettantervek alapján azonban meglehetősen nehéz a szintézisalkotás és a tantárgyi integráció a két tantárgy között. Ennek okát a tananyagelrendezésben és a földrajz tantárgy óraszámcsökkentésében látom, az új tantervi szabályozók a korábbiakhoz képest is nehezebb helyzetbe hozzák azokat a pedagógusokat, akik tudatosan szeretnének építeni a két tantárgy kapcsolatára. Az állampolgári nevelésen és a gazdasági ismeretek átadásán kívül - hogy csak néhány példát 
említsünk - mindkét tantárgynak jelentős szerepe van a téri készségek fejlesztésében, a helyes időképzet kialakításában és a mindennapokban (pl. a média vagy a politika világában) való sikeres tájékozódás előmozdításában. Napjainkban, amikor a tantervi szabályozók nemhogy nem segítik, hanem - szándékuk ellenére - sok esetben hátráltatják a tantárgyak közötti szintézisalkotást és együttmüködést, kifejezetten fontos a pedagógusok szerepe (SEREs Z. 2021), a jövő iskolájának egyik alappillére a közöttük lévő együttműködés (Вотоs R. - PAVEszKa D. 2020). Szükség van arra, hogy kiépítsük a különböző műveltségterületek (esetükben a Történelem és állampolgári ismeretek és a Természettudomány és földrajz) közötti kapcsolatokat, összefüggéseket (KeRBER Z. 2009). Ennek ellenére a hazai szakirodalom kevéssé foglalkozik a két tantárgy köznevelési rendszeren belüli kapcsolataival.

E tanulmány célja áttekinteni a földrajz és a történelem tantárgy kapcsolatát a köznevelési rendszerben, a dokumentumelemzés módszerével megvizsgálni a kerettantervek alapján a szintézisalkotásban rejlő lehetőségeket, valamint megfogalmazni módszertani ajánlásokat a két tantárgy eredményesebb tanításával kapcsolatban. Terjedelmi korlátok miatt nincs lehetőség a teljes körű, rendszerező áttekintésre, csupán néhány kiragadott példán keresztül szemléltetem a lehetséges kapcsolódási pontokat, ötleteket adva a szakmai-szakmódszertani gondolkodás elindításához.

\section{A FÖLDRAJZ ÉS A TÖRTÉNELEM TANTÁRGY MÚLTJA ÉS JELENE}

A földrajz és a történelem tantárgy kapcsolata igen szoros. A magyarországi földrajzoktatás korai időszakában, a 17-18. században a földrajz tantárgy (ami ekkor ugyan még mást jelentett, mint napjainkban) a történelemhez volt „láncolva”. Az 1777-es Ratio Educationis kiemelkedő jelentőségü volt a tantárgy szempontjából, ugyanis a rendelkezés a földrajzot önálló és kötelezö tantárggyá tette. Azonban a II. Ratio Educationis (1806) bevezetését követően (részben) újra megszűnt a tantárgy önállósága - vagy a történelemmel tanították, vagy önállóan (TEPERICs K. et al. 2015) -, ami visszavetette a fejlődését (MAKádi M. 2020a). 1848 után a földrajz hol a történelemhez kapcsolt, hol önálló tantárgyként jelent meg a tantervekben. Jelentős lépés volt, hogy az 1868-as Eötvös József-féle iskolatörvény az oktatás minden szintjén kötelezö tantárggyá tette (MAKÁDi M. 2020a), sőt az érettségi tantárgyak közé is bekerült (TePerics K. et al. 2015). Ezt követően önálló tantárgyként a történelemmel való szoros kapcsolata fennmaradt. Ez a folyamat a szocializmus időszakában kissé megváltozott, mert akkor a földrajz természettudományi oldala került előtérbe. A 2020-as Nemzeti alaptantervben jelentős változás, hogy a földrajz elvesztette - az 1995-ös Nemzeti alaptanterv megjelenésétől kezdve meglévő - önálló műveltségterületi létét, a hagyományos természettudományos 
kapcsolat fennmaradása mellett önálló részterület lett (FARsANG A. - ÜTőNÉ VISI J. 2020): a biológia, a fizika, a kémia és a földrajz tantárgyak a Természettudomány és földrajz müveltségi területbe tartoznak. Napjainkban az egyik legnagyobb problémát az óraszámok 1950-es évektől megfigyelhető csökkenése okozza (TEPERICs K. et al. 2015), legutóbb mind a 2012-es, mind a 2020-as NAT csökkentette a földrajz óraszámát 1-1 órával. Az 1960-as években egy érettségiző tanuló mögött még hét évnyi (4+3 év) földrajztanulás állt (MAKÁDi M. 2020a), szemben a mai négy évvel (2+2 év) (1. táblázat). A történelemtanítás sincs könnyü helyzetben, paradox módon számos történelemtanár vagy arról panaszkodik, hogy túlzottak a követelmények, vagy arról, hogy azok egyre minimálisabbak, az állandó változások pedig kiszámíthatatlanná teszik a pedagógusok munkáját (KAPOsi J. 2020). Úgy vélem, hogy előbbiek a földrajztanárok - sőt, valamennyi tanár - számára is nehézséget okoznak.

A földrajz tantárgynak napjainkban a legszorosabb kapcsolata a történelemmel van, hiszen a tananyaga sok szempontból kapcsolódik a földrajzi térhez, de a kapcsolat szorosságát az is erősítheti, hogy a földrajztanárok másik szakja a legtöbb esetben különösen a frissen végzett tanárok vonatkozásában - a történelem (vö. ÜTőNÉ VISI J. 2009). Az említett tantárgyak mellett a földrajz szorosan kapcsolódik a biológiához, a fizikához, a kémiához és a matematikához is. „A földrajzi tartalmak más tantárgyak keretei között történö megjelenése természetes folyamat” (TEPERICs K. et al. 2015. p. 172.). A földrajz tantárgy interdiszciplináris jellegét mutatja, hogy a tanulása során megszerzett ismeretek széles körben felhasználhatók az oktatás más területein (pl. a természettudományos és társadalomtudományos tantárgyak esetében) is (ÜTőNÉ VISI J. 2009), ám ugyanez elmondható a történelemórán megszerzett ismeretekről is. A történelemórákon számos területen építünk a diákok földrajzi ismereteire, de le kell szögezni, hogy ez nem csak a topográfiai ismeretek hasznosítását jelenti. A természetföldrajzban tanultak (növényi kultúrák elterjedése, vulkáni tevékenység stb.) vagy a gazdaságföldrajzi ismeretek (világkereskedelem jellegzetességei, ásványkincsek gazdasági hasznosítása stb.)

\begin{tabular}{|c|c|c|c|c|c|}
\hline & 7. évfolyam & 8. évfolyam & 9. évfolyam & 10. évfolyam & 11. évfolyam \\
\hline Földrajz & 2 & 1 & 2 & 1 & $2^{*}$ \\
Történelem & 2 & 2 & 2 & 2 & 3 \\
Összesen & 4 & 3 & 4 & 3 & 5 \\
\hline
\end{tabular}

1. táblázat. A 2020-as Nemzeti alaptanterv ajánlása a földrajz és a történelem tantárgyak alapóraszámára az alapfokú és a gimnáziumi képzés nevelési-oktatási szakaszaihoz (a Nemzeti alaptanterv 2020 alapján szerk. SERES Z.)

* A 11. évfolyamon heti két órában lehetősége van földrajzot tanulnia azoknak a tanulóknak, akik nem tanulnak emelt óraszámban vagy fakultáción természettudományos tantárgyat, feltéve, ha az adott iskola nem az integrált természettudomány tantárgyat választja. 
nélkül a tanulók számos, a gazdaságtörténethez kapcsolódó témával kapcsolatban csak nehezen tudnák értelmezni magyarázatainkat (SzÁrAY M. 2010). A történelmi események helyszíneinek megtanulásához, a gazdaságtörténet feldolgozásához elengedhetetlenek a földrajzi ismeretek (ÜTŐNÉ VISI J. 2009), ugyanakkor az egyes országcsoportok vagy országok tanulása során szükséges ismernünk azok történelmi múltját is annyiban, amennyiben az meghatározza a jelen társadalmi-gazdasági folyamatait. Talán nem túlzás, ha azt mondjuk, hogy földrajz nélkül nincs történelem, történelem nélkül pedig nincs földrajz.

Napjaink tanítási gyakorlatában jelentős problémát okoz, hogy a földrajz tantárgy 10. évfolyamon való befejezése megakadályozza a történelem tantárggyal való eredményes tantárgyi koncentrációt. A tantervi szabályozók „túl korán és megfelelö történelmi ismeretek hiányában késztetik a tanulókat az életkori sajátosságaiknak sem mindenben megfelelö, szintetizáló jellegü tananyag elsajátítására" (ÜTőNÉ VISI J. 2009). A helyzetet nehezíti, hogy a 2020-as tantervi szabályozók alapján valamennyi természettudományos tantárgy tanítása is befejeződik a 10. évfolyam végén, így még kevésbé van lehetőség a történelemmel való kapcsolódási pontokban, az integrációban és a szintézisalkotásban rejlő lehetőségek felhasználására. A középiskola első két évfolyamának témakörei ugyanis az ókortól a 19. század közepéig ölelik fel az emberiség történelmét (Kerettanterv a gimnáziumok számára, Történelem, 2020), így elsőre meglehetősen kevés téma tủnik olyannak, amit össze tudunk kapcsolni a földrajzzal, bár a mélységelvü órákban rejlenek lehetőségek (SEREs Z. 2021).

\section{A FÖLDRAJZ ÉS A TÖRTÉNELEM TANTÁRGY SAJÁTOSSÁGAI A 7-10. ÉVFOLYAMOKON}

A jelenleg hatályos tantervi szabályozók alapján a tanulók önálló tantárgyként az 5-12. évfolyamokon tanulnak történelmet. Mivel földrajztanítás csupán a 7-10. évfolyamokon van, így a történelem tantárgy helyzetét is ezeken az évfolyamokon vizsgálom, bár néhol elengedhetetlen a kitekintés a többi évfolyamra is. Itt megjegyzendő, hogy a két tantárgy óraszámaiban tapasztalható torz arány nemzetközi összehasonlításban példa nélküli (РRовÁLD F. 2017): amíg a magyar köznevelési rendszerben a felső tagozaton és a gimnáziumban összesen 18 tanóra áll rendelkezésre a történelem tantárgy tanítására, addig ugyanebben az időintervallumban harmadannyi, mindössze 6 tanóra jut földrajztanításra.

A történelemtanítás a vizsgált évfolyamokon alapvetően kronologikus elrendezésü (ez a rendezőelv a középiskolai szakaszban válik meghatározóbbá), az egyetemes és a magyar történeti témák mind a 7-8., mind a 9-10. évfolyamokon vegyesen, korszakokhoz 
köthetö témakörökbe rendezve jelennek meg (Nemzeti alaptanterv, 2020). „A 9-12. évfolyamok tanterve spirális módon épül az 5-8. évfolyamokéra, és nem ismétli automatikusan azokat" (Nemzeti alaptanterv, 2020. p. 345.). A tanulók a 7-8. évfolyamokon a 19. század közepétől egészen napjainkig veszik sorra a történelmi eseményeket, míg a 9-10. évfolyamokon a kezdetektől 1848-1849-ig. Ebből jól látható, hogy amennyiben a tanulók középfokú tanulmányaikat gimnáziumban folytatják, a négy évig (7-10. évfolyam) tartó földrajztanulással párhuzamosan a történelemórákon az emberiség teljes történelmével megismerkedhetnek, jóllehet (a földrajztanítás szempontjából) nem a szokványos időrendben.

A földrajztanítás-tanulás a 7. évfolyamon a természettudományos szaktantárgyakkal párhuzamosan kezdődik és a 10. évfolyamon azokkal párhuzamosan ér véget. A 7-8. évfolyamon a földrajzi tartalmak tárgyalása a közelitöl a távoli felé (közvetlen lakóhelyünk, Magyarország, Európa, távoli kontinensek földrajza, globális folyamatok) elvet követi (lineáris tananyagelrendezés). A középiskolai földrajz tanterv ismeretrendszere többnyire koncentrikus módon épül az általános iskolaira, a 9-10. évfolyamon a földrajzi tananyag a természeti és a társadalmi környezet összefüggéseivel és kölcsönhatásaival foglalkozik (Nemzeti alaptanterv, 2020), az általános iskolában tanultakhoz képest magasabb szinten. A középiskolában a földrajz tantárgy a múltból kiindulva a jelen folyamataira, jelenségeire és azok lehetséges jövőbeli következményeire összpontosít, egyaránt építve a térképi, a grafikus és a szöveges adatforrásokból megszerezhető információkra (Kerettanterv a gimnáziumok számára, Földrajz, 2020).

A 2. táblázat évfolyamokra lebontva mutatja be a két tantárgy kerettantervben megadott nagy témaköreit, az azok feldolgozására javasolt óraszámokat, valamint hozzávetőlegesen azt is, hogy az egyes tantárgyak témakörei időben hol helyezkednek el a másik tantárgy témaköreihez képest (pl. amíg a 9. évfolyamon földrajzórákon a tanulók a légkörről tanulnak, addig történelemórákon az ókori, illetve kora középkori hódító birodalmakról). Nehezíti az átláthatóságot, hogy míg a történelem tantárgyat a vizsgált évfolyamokon heti 2 órában tanulják a tanulók, addig a földrajzot a 8. és a 10. évfolyamokon csupán heti 1-1 órában. Ez utóbbi azt jelenti, hogy egységnyi idő alatt kétszer annyi tanórájuk van a tanulóknak történelemből, mint földrajzból, így gyorsabban haladnak, több ismeretre tesznek szert. A táblázat csak nagy vonalakban mutatja be a két tantárgy szinkronját, hiszen egyrészt meglehetősen bonyolult ezt ábrázolni, másrészt a valóság (pl. a helyi tantervek eltérései, óraelmaradások, zsúfolt tananyag) ezt sok esetben felülírhatja, harmadrészt - különösen a földrajz esetében - csak nehezen oldható meg az óraszámok arányos elosztása az évfolyamokon. Ennek ellenére a táblázatból már első pillantásra is látszik, hogy a fő probléma az időrend egyeztetése: viszonylag kevés egymással kapcsolatban hozható témáról tanulnak a tanulók egy időben a földrajz- és a történelemórákon. 


\begin{tabular}{|c|c|c|c|}
\hline Témakör címe - Földrajz & $\begin{array}{l}\text { Javasolt } \\
\text { óraszám }\end{array}$ & $\begin{array}{l}\text { Javasolt } \\
\text { óraszám }\end{array}$ & Témakör címe - Történelem \\
\hline \multicolumn{4}{|c|}{ 7. évfolyam } \\
\hline Tájékozódás a földrajzi térben & 4 & 5 & A modern kor születése \\
\hline Közvetlen lakókörnyezetünk földrajza & 5 & 7 & $\begin{array}{r}\text { A dualizmus kora: felzárkózás Európá- } \\
\text { hoz }\end{array}$ \\
\hline \multirow[t]{3}{*}{ Magyarország földrajza } & \multirow[t]{3}{*}{25} & 11 & Az első világháború és következményei \\
\hline & & 5 & Totális diktatúrák \\
\hline & & 9 & A Horthy-korszak \\
\hline A Kárpát-medence térsége & 8 & 10 & A második világháború \\
\hline \multirow[t]{2}{*}{ Európa földrajza } & \multirow[t]{2}{*}{22} & 5 & A megosztott világ \\
\hline & & 10 & Magyarország szovjetizálása \\
\hline Az Európán kívüli kontinensek földrajza I. & 4 & 6 & Két mélységelvű téma \\
\hline \multicolumn{4}{|c|}{ 8. évfolyam } \\
\hline \multirow[t]{3}{*}{ Az Európán kívüli kontinensek földrajza II. } & \multirow[t]{3}{*}{16} & 20 & A forradalomtól az ezredfordulóig \\
\hline & & 8 & Együttélés a Kárpát-medencében \\
\hline & & 5 & Népesedés és társadalom \\
\hline \multirow[t]{2}{*}{ A földrajzi övezetesség rendszere } & \multirow[t]{2}{*}{8} & 7 & A demokratikus állam \\
\hline & & 14 & Régiók története \\
\hline \multirow[t]{2}{*}{ Életünk és a gazdaság: a pénz és a munka világa } & \multirow[t]{2}{*}{10} & 8 & Mérlegen a magyar történelem \\
\hline & & 6 & Két mélységelvű téma \\
\hline 7-8. évfolyam összesen & 102 & 136 & 7-8. évfolyam összesen \\
\hline \multicolumn{4}{|c|}{ 9. évfolyam } \\
\hline Tájékozódás a kozmikus térben és az időben & 6 & 13 & Civilizáció és államszervezet az ókorban \\
\hline A kőzetburok & 11 & 5 & Vallások az ókorban \\
\hline A légkör & 9 & 6 & Hódító birodalmak \\
\hline A vízburok & 7 & 10 & A középkori Európa \\
\hline A geoszférák kölcsönhatásai és összefüggései & 15 & 14 & A magyar nép eredete és az Árpád-kor \\
\hline $\begin{array}{r}\text { Átalakuló települések, eltérő demográfiai problé- } \\
\text { mák a 21. században }\end{array}$ & 7 & 13 & A középkori Magyar Királyság fénykora \\
\hline $\begin{array}{r}\text { Helyi problémák, globális kihívások, a fenntartha- } \\
\text { tó jövő dilemmái }\end{array}$ & 14 & 7 & Két mélységelvű téma \\
\hline \multicolumn{4}{|c|}{ 10. évfolyam } \\
\hline \multirow[t]{3}{*}{ A nemzetgazdaságtól a globális világgazdaságig } & \multirow[t]{3}{*}{17} & 12 & A kora újkor \\
\hline & & 10 & A török hódoltság kora Magyarországon \\
\hline & & 7 & A felvilágosodás kora \\
\hline \multirow{2}{*}{$\begin{array}{r}\text { Magyarország és Kárpát-medence a 21. század- } \\
\text { ban }\end{array}$} & \multirow[t]{2}{*}{9} & 10 & Magyarország a 18. században \\
\hline & & 5 & Új eszmék és az iparosodás kora \\
\hline \multirow[t]{3}{*}{ A pénz és a tőke mozgásai a világgazdaságban } & \multirow[t]{3}{*}{7} & 10 & A reformkor \\
\hline & & 8 & A forradalom és szabadságharc \\
\hline & & 6 & Két mélységelvű téma \\
\hline 9-10. évfolyam összesen & 102 & 136 & 9-10. évfolyam összesen \\
\hline
\end{tabular}


2. táblázat. A földrajz és a történelem tantárgy témakörei és javasolt óraszámai a 2020-as kerettantervek alapján a 7-10. évfolyamon (a Kerettanterv az általános iskolák és a gimnáziumok számára - Földrajz, Történelem, 2020 alapján szerk. SEREs Z.)

Ez önmagában azonban nem jelenthet nagy problémát, hiszen hosszabb (akár egyéves) időeltolódás sem lehet akadálya az ismétlö-elmélyítő felidézésnek (BÁNKUTi Zs. et al. 2011). Ebből kiindulva például a 10. évfolyam elején, a földrajzi felfedezéseknél visszautalhatunk az előző évi földrajzórákra (vö. passzátszelek), sőt a török hódoltság koránál is megemlíthetjük azokat a térségeket, ahol az aprófalvas szerkezet még napjainkban is domináns (vö. településföldrajz vagy Magyarország a 21. században). Ennél nagyobb nehézséget jelenthet a tényleges tanári elkötelezettség hiánya, aminek oka lehet, hogy a tanárok többsége nincs igazán felkészítve - már a tanárképzés során sem - a tantárgyi integráció megvalósítására, vagyis nem tudja, hogy az hogyan jelenjen meg az oktatásban (vö. KojANitz L. 2018). Nehezíti a helyzetet az is, hogy bár a tantárgyi integráció megjelenik a NAT-ban, az új tantervekben különválnak egymástól az integrálandó tantárgyak (KoJANITz L. 2018), így a mai magyar oktatási rendszerből többnyire „hiányzik a komplex, tantárgyakat átívelö és integráló témákban való elmélyülés lehetösége" (Czirfusz M. - Gyapay B. 2018. p. 5.). Probléma tehát, hogy - talán az előbbiekben is gyökerezve - a tanulók nem képesek összekapcsolni egymással a különböző tantárgyak tanítási óráin szerzett tudást. Amennyiben van rá mód, érdemes élni a külső tartalmi koncentráció lehetőségével. A szűk időkeretek okozta problémákat enyhítheti (ha meg nem is oldhatja), ha a más tantárgyak óráin megtanított tartalmakat csak bekapcsoljuk a földrajzoktatásba, a tények, a jelenségek részletező tanítása helyett csupán beillesztjük azokat a földrajz rendszerébe, összefüggéseibe (TePERICs K. et al. 2015).

\section{A KÉT TANTÁRGY KERETTANTERVEINEK ÖSSZEHASONLÍTÁSA A SZINTÉZISALKOTÁS VONATKOZÁSÁBAN}

A tanulmánynak ebben a részében a két tantárgy kerettanterveiben megfogalmazott legfontosabb közös célokat gyüjtöm össze, majd három nagyobb blokkon keresztül bemutatok azon szempontok, kapcsolódási pontok közül néhányat, amelyekre a két tantárgy tanulása-tanítása során építhetünk.

A történelemtanítás kiemelt célja, hogy a tanulókban tudatosuljon nemzeti hovatartozásuk, azonosuljanak kultúránk alapértékeivel, kialakuljon bennük a tényeken alapuló reális és pozitív nemzettudat, ezáltal erősödjön bennük a hazaszeretet érzése (Kerettanterv a gimnáziumok számára, Történelem, 2020). Hazánk nemzeti értékeinek és a globális világban betöltött szerepének megismertetésével a földrajz tantárgy is hozzájárul a szülőföldhöz és a magyarsághoz való kötődés kialakításához és 
elmélyítéséhez (Kerettanterv a gimnáziumok számára, Földrajz, 2020). Fontos, hogy a tanulók lássák, tudásuk az „iskolán kívül, más élethelyzetekben, illetve a jelen társadalmi, gazdasági és politikai jelenségeinek megértéséhez és megitéléséhez is segítséget nyújt” (Kerettanterv a gimnáziumok számára, Történelem, 2020. p. 1.). A földrajz kerettanterv alkotói is fontosnak tartják, hogy az iskolából kilépő tanulók képesek legyenek felelős döntéshozatalra az állampolgári szerep gyakorlása során (Kerettanterv a gimnáziumok számára, Földrajz, 2020).

A tantárgyaknak a digitális kompetenciák fejlesztésében is nagy szerepük van: a történelem tanulása során az IKT-eszközök etikus, felelősségteljes használatával fejlődnek a tanulók információkezelési és -feldolgozási készségei, a digitális kommunikáció fejlesztése pedig fontos a közéleti tájékozódási készségek kialakításában, így a felelős és aktív állampolgárrá nevelésben (Kerettanterv a gimnáziumok számára, Történelem, 2020). A korszerü földrajzoktatás is elképzelhetetlen a digitális világ nyújtotta aktuális információk tanításba való beépítése nélkül, így a tanulási-tanítási folyamat tudatosan épít például a digitális térképek, térinformatikai szoftverek alkalmazására, elemzések elvégzésére (Kerettanterv a gimnáziumok számára, Földrajz, 2020).

A két tantárgy kulcsfogalmai, fejlesztési céljai között számos átfedés található, ám ezeket az esetek túlnyomó részében nem egy időben, nem egymással párhuzamosan tanulják a tanulók. A kapcsolódási pontokat három nagyobb csoportba soroltam a könnyebb átláthatóság érdekében: (1) topográfiai-téri, (2) gazdaságföldrajzi-gazdaságtörténeti, (3) társadalomföldrajzi-társadalomtörténeti jellegü fejlesztési feladatok és kulcsfogalmak. Ez a felosztás nem objektív és nem egzakt, csupán egy általam praktikusnak vélt csoportosítása a vizsgált területeknek, hiszen az egyes csoportok közötti vonalak nem húzhatók meg vonalzóval, azok gyakorta összemosódnak. Ugyanakkor úgy vélem, hogy e három csoportba valamennyi fejlesztési feladat és kulcsfogalom elhelyezhető - még ha esetleg csak érintőlegesen is.

\section{TOPOGRÁFIAI-TÉRI JELLEGÜ FEJLESZTÉSI FELADATOK ÉS KULCSFOGALMAK}

A térképek mind a történelem, mind a földrajz tanítás-tanulásának nélkülözhetetlen eszközei; az állandó térképhasználat, a térben való tájékozódás folyamatos fejlesztése egyaránt megkönnyítheti a pedagógusok és a tanulók munkáját a történelmi-földrajzi gondolkodás alakításában, a térképek segítik, alátámasztják az ismeretszerzést és a készségfejlesztést. A tanulók elsősorban a földrajzi tanulmányaik során szerzik meg a térképekkel kapcsolatos alapvető ismereteket, amikre építenünk kell a történelemórákon is (Száray M. 2010). Az előbbi állítást azonban árnyalja, hogy a tanulók hamarabb kezdik a történelmet 
tanulni (5. évfolyam), mint a földrajzot (7. évfolyam), ráadásul a 2020-as tantervi szabályozók meglehetősen szűk időkeretet biztosítanak a földrajzi térben való tájékozódás és az azzal kapcsolatos ismeretek tanítására. 2020-tól már csak a 7. évfolyam első négy tanóráján foglalkozunk konkrétan (a Tájékozódás a földrajzi térben címü témakörön belül) ilyen jellegü ismeretekkel, a 9. évfolyam elejéről számüzték ezt a témakört. Ezért is lényeges, hogy pedagógusként ismerjük, hogy diákjaink mit tudnak vagy mit kellene tudniuk, annak érdekében, hogy építeni tudjunk a más tantárgyak tanóráin megszerzett ismeretekre. A tantárgyi koncentráció szükségessége vitathatatlan (SzÁRAY M. 2010).

\section{Topográfiai jellegü fejlesztési feladatok és kulcsfogalmak (névanyag)}

Mindkét tantárgy kerettanterve jelentős mennyiségű topográfiai fogalom (névanyag) megtanítását-tanulását várja el a tanároktól és a tanulóktól. A 3. táblázat azt mutatja meg, hogy a 7-10. évfolyamon melyek azok a topográfiai fogalmak, amelyek mindkét tantárgy kerettanterveiben megtalálhatók. Igen meglepő, hogy míg Róma vagy India mindkét dokumentumban szerepel, addig Athén, Belgrád (Nándorfehérvár), a Nílus vagy a Kárpát-medence csak a történelem kerettantervben. Természetesen, azok a tanulók, akik érettségiznek földrajzból, találkoznak mind a négy imént említett topográfiai fogalommal, hiszen azok szerepelnek a vizsgakövetelményekhez kapcsolódó topográfiai fogalmak listáján (2021). Mindenesetre érdekes, hogy Athént vagy Belgrádot miért nem, Rijádot vagy Seattle-t pedig miért tartalmazza a 2020-as földrajz kerettanterv. A 2012-es földrajz kerettantervben még sem Róma, sem Athén nem szerepelt konkrétan megnevezve, ám a topográfiai ismereteknél az „Európa országai és fövárosai” elnevezés e két város mellett Belgrádot is magában foglalta. Kissé következetlennek tartom az új kerettanterv topográfiai követelményekkel kapcsolatos részeit, hiszen mitől fontosabb Róma, mint Athén? Számomra elképzelhetetlen, hogy amikor Görögországról tanítunk földrajzórán (a meglehetősen szűk időkeretben), ne említsük és mutassuk meg térképen annak fővárosát (vagy ne említsük meg annak a világtörténelemre gyakorolt hatásait), mint ahogyan az is, hogy Magyarország tanítása során ne mutassuk meg a Kárpát-medence elhelyezkedését Európa és Magyarország viszonylatában. Még akkor is, ha az 5-6. évfolyamokon tanult természettudomány tantárgy tanulásának eredményeként a tanulók már megfogalmazzák Európa és Magyarország tényleges és viszonylagos földrajzi fekvését (Kerettanterv az általános iskolák számára, Természettudomány, 2020). Ezeket a dokumentumokban lévő, valószínüleg nem szándékos ellentmondásokat tanárként ugyan fel tudjuk oldani, ám érdemes lenne ezeket már a kerettantervek összeállításánál figyelembe venni, valamint felhasználni, racionalizálni a tantárgyak közötti átfedéseket. 
Ahogyan a 3. táblázatból is látható, számtalan olyan topográfiai fogalom található a kerettantervekben, amely mindkét tantárgy tanulása során szóba kerül a vizsgált négy évfolyamon. A 9. évfolyamon például három világvallás központja (Róma, Jeruzsálem, Mekka) kétszer is előkerül: először történelemből az első félévben (Vallások az ókorban, Hódító birodalmak), másodszor földrajzból a második félévben (Átalakuló települések, eltérő demográfiai problémák a 21. században). Ebben az esetben mindkét szaktanárnak nagy felelőssége van abban, hogy a három említett várost és a hozzájuk kapcsolódó civilizációs-kulturális ismereteket a lehető legalaposabban, széles kapcsolatrendszerében tanítsa meg a tanulóknak. Történelemórán a zsidó, a keresztény és az iszlám vallással kapcsolatos alapvető történelemi eseményekkel (pl. kialakulás, elterjedés) és jellegzetességekkel (pl. Ószövetség, Szentháromság, az iszlám vallás öt pillére) ismerkednek meg a tanulók, míg földrajzórán a vallások társadalmi-gazdasági életre gyakorolt hatásaival (pl. életmód, politikai döntések, születésszabályozás). Ez ugyan leírva meglehetősen egyszerünek tünik, ám történelemórán nem tudjuk e témákat úgy megtanítani, hogy ne használnánk azokhoz földrajzi jellegü ismereteinket (gondoljunk csak a városok elhelyezkedésére vagy a vallások elterjedésére), mint ahogyan földrajzórán sem igen tudunk e vallásokról történelmi ismeretek nélkül beszélgetni (pl. Izrael politikai helyzete

\begin{tabular}{|c|c|}
\hline Évfolyam & Topográfiai névanyag \\
\hline $7-8$. & $\begin{array}{r}\text { Újkor, jelenkor } \\
\text { Amerikai Egyesült Államok, Japán; } \\
\text { Kárpátalja, Felvidék, Délvidék, Burgenland, Erdély; } \\
\text { Szibéria; } \\
\text { Dél-Korea; } \\
\text { Hortobágy, Duna-delta; } \\
\text { Izrael. }\end{array}$ \\
\hline $9-10$. & $\begin{array}{r}\text { Ókor, kora középkor } \\
\text { Egyiptom, Alexandria, Róma, Jeruzsálem; } \\
\text { Izrael, Konstantinápoly (Isztambul*), Mekka; } \\
\text { Középkor } \\
\text { Egyházi Állam (Vatikán), Anglia (Egyesült Királyság, Nagy-Britannia), Franciaország, Velence; } \\
\text { Pannonhalma, Esztergom, Székesfehérvár, Horvátország; } \\
\text { Visegrád, Lengyelország, Csehország; } \\
\text { Kora újkor, újkor } \\
\text { Spanyolország, India, London, Párizs, Sárospatak; } \\
\text { Mohács, Kőszeg, Eger, Bécs; } \\
\text { Amerikai Egyesült Államok, Oroszország; } \\
\text { Manchester, New York; } \\
\text { Pest-Buda (Budapest); } \\
\text { Debrecen, Komárom. }\end{array}$ \\
\hline Összesen & 46 \\
\hline
\end{tabular}

3. táblázat. A 2020-as kerettantervekben szereplö topográfiai névanyag földrajz és történelem tantárgyakból. A táblázat csak a mindkét tantárgy kerettantervében megtalálható névanyagot tartalmazza, az egyes történelmi korszakokhoz kapcsolva azokat. (a Kerettanterv az általános iskolák és a gimnáziumok számára - Földrajz, Történelem, 2020 alapján szerk. SERES Z.)

${ }^{*} A$ dölt betüvel szedett topográfiai fogalmak a földrajz kerettantervben szereplö elnevezéseket jelentik. 
napjainkban). Éppen ezért nem szerencsés a történelemtanítást a múltban lezárni, a földrajztanítást pedig a jelennel kezdeni. A történelemórába a múltbéli események mellett be kell építenünk azt is, hogy napjainkban milyen meghatározó jellegzetességekkel rendelkeznek az egyes vallások vagy azok a világ mely részein terjedtek el, hiszen ez elengedhetetlen azon ok-okozati, illetve társadalmi-gazdasági összefüggések megértéséhez, amelyekre földrajzórán építhetünk. A történelemtanítás nagyon sokban segítheti a földrajztanárok munkáját (és fordítva is), akiknek a téma adott óráját már nem e városok térbeli elhelyezkedésével vagy a vallások történelmi gyökereivel kell indítaniuk, hanem egy sokkal magasabb szintről, ahol már ténylegesen az összefüggéseken van a hangsúly. Mindez kifejezetten fontos, hiszen egyrészt ezek a témák nem egy időben kerülnek elő a két tantárgy esetében ( $k b$. fél év van közöttük), másrészt a földrajz lecsökkent időkeretéből kifolyólag nincs arra idő, hogy újra tanítsuk mindazt, amit korábban történelemórán már tanul(hat)tak a tanulók.

Érdemes utalni a két tantárgy közötti kapcsolatokra azon magyar városok esetében is, amelyekkel mindkét tantárgy során találkoznak a tanulók. Erre jó példa lehet Pannonhalma, ahol a 996-ban (Géza fejedelem, illetve I. (Szent) István idejében) alapított, majd 1996-ban az UNESCO Világörökség listájára felkerült Pannonhalmi Bencés Főapátság található. Az előbbi mondatban mind történelmi (Géza és István, bencés szerzetesrend), mind földrajzi jellegü (UNESCO Világörökség) is fellelhetö, így mindkét tantárgy keretein belül megemlíthetö. Debrecen „kálvinista Róma” elnevezése is nehezen értelmezhetö történelmi ismeretek nélkül, jellegzetes épülete - a Nagytemplom - is új megvilágításba kerülhet földrajzórán a történelmi gyökerek ismeretében. Székesfehérvár történelmi szerepére - pl. középkori koronázóváros, az Aranybulla kiadásának helyszíne - is utalhatunk földrajzórán, amikor a Közép-Dunántúl régió központjáról, hazánk egyik közlekedési csomópontjáról tanulunk. Az imént említett három város csupán példák annak alátámasztására, hogy érdemes egyik vagy másik órán utalásokat tennünk vagy korábban tanult ismereteket felidéztetnünk, hiszen így a tanulókban is tudatosulhat, hogy amit történelem- vagy földrajzórán tanulnak, az nem csak az adott tanórán - sőt, egyáltalán nem csak tanórán - használható.

\section{Téri jellegü fejlesztési feladatok és kulcsfogalmak}

A 2020-as történelem kerettanterv sok esetben megfogalmaz olyan fejlesztési feladatokat, amelyek térképekkel, térképhasználattal kapcsolatosak (pl. A népvándorlás irányainak és résztvevőinek nyomon követése térkép segítségével a Kr. u. 4-8. sz. időszakában; A felfedezők céljainak és útjainak bemutatása tematikus térképeken; Magyarország újranépesülésének és a folyamat eredményének értelmezése tematikus 
térképek segítségével; A történelmi Magyarország szétesésének bemutatása térképen az elcsatolt területek történelmi megnevezésével). Sőt az új típusú érettségi feladatlapokban is gyakran találkozhatunk térképekkel kapcsolatos feladatokkal. A fejlesztési feladatok valamennyi esetben nemcsak egy-egy térképhez kötődnek, hanem valamilyen természetföldrajzi vagy társadalomföldrajzi folyamathoz is. Érdemes ezekre is felhívni a tanulók figyelmét. A földrajzi felfedezéseknél említsük meg, hogy mely mai országok területén és hogyan zajlott a gyarmatosítás, illetve mindennek milyen (társadalmi, gazdasági, politikai) következményei lehetnek napjainkban, Magyarország 18. századi újranépesülése pedig csak úgy érhető meg teljes egészében, ha használunk alapvető földrajzi jellegű fogalmakat (pl. belső és külső migráció, nemzetiségek).

Mindehhez a kiindulópontot sok esetben a térképek jelenthetik. A téri készségek fejlesztése a földrajztanítás egyik legnagyobb kihívása (MAKÁDI M. 2020b), ám nem egyedül e tárgy feladata, abban jelentős szerepet kell vállalnia más tantárgyaknak (pl. a történelemnek) is. A térszemlélet interdiszciplináris jellegével túlnyúlik a köznevelési rendszer tantárgyi keretein, számos iskolai fejlesztési területet kapcsol össze, ám az egyes tantárgyak oktatási gyakorlatában egymástól függetlenül, sok esetben az összehangolás igénye nélkül történik a fejlesztés (BABÁLY B. - KÁrpátı A. 2015). A tanulók térbeli intelligenciája, téri képességeik leginkább akkor fejlődnek, ha például a tanulás során mentális térképeket alkothatnak, a tartalmakat vizuálisan rendezhetik vagy lehetőséget kapnak müvészi kifejezésre (MAKÁDI M. 2020b). Erre mindkét tantárgy esetében van lehetőség. A földrajzi felfedezéseknél a világkereskedelem kibontakozását jól szemléltethetik a térképek, de egy adott térkép alapján mi magunk is készithetünk valamiféle vizuális rendezőt. A tanulók kapnak egy-egy elöre kinyomtatott lapot (természetesen meg is rajzoltathatjuk velük azt), amit közösen, de önálló munkában töltünk meg tartalommal (1. ábra). A sematikus ábra elkészítéséhez a tanulók a tankönyvi térképet (vagy szöveget) használják. A tanulói produktum nemcsak történelemórán, hanem földrajzórán is jól használható, utóbbin például $A$ nemzetgazdaságtól a globális világgazdaságig címü tematikus egység Az amerikai gazdasági erötér fejezet feldolgozása kapcsán, amit (elméletileg) a földrajzi felfedezésekkel hozzávetőlegesen párhuzamosan tanulnak a tanulók földrajzórán. Itt beszélgethetünk arról, hogy mi változott az elmúlt fél évezredben a kontinensek kereskedelmi kapcsolataiban, vagy milyen termékekkel vannak jelen napjainkban a latin-amerikai országok a világpiacokon. Mindehhez természetesen elengedhetetlen, hogy a pedagógusok együttmüködjenek egymással, jó módszer lehet tehát, ha a történelemórán rajzolt sematikus ábrát a földrajzórán is használtatjuk a tanulókkal, kiegészítve, aktualizálva mindazt, ami azon szerepel.

A jelenleg forgalomban lévő történelemkönyvek és történelmi atlaszok térképeinek áttekintéséből látható, hogy azok többségében tematikus térképeket tartalmaznak, illetve 


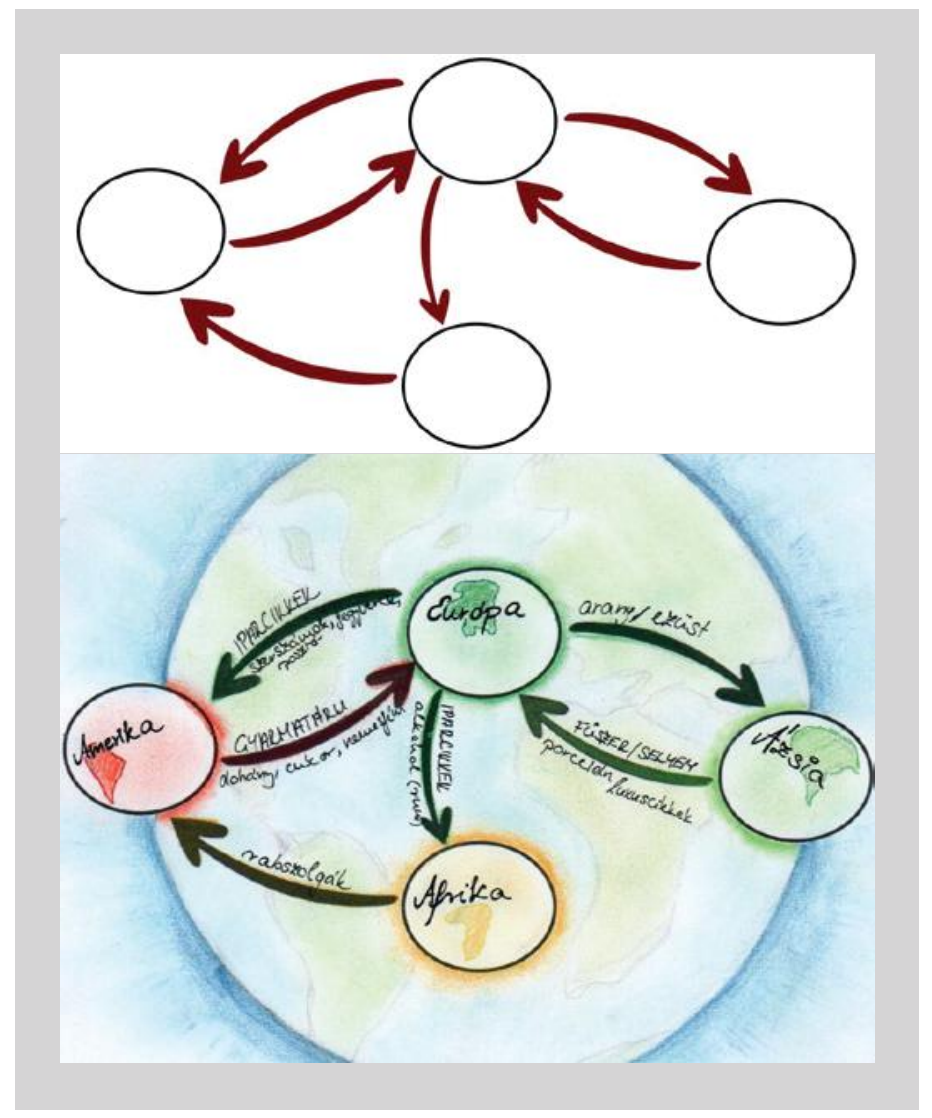

1. ábra. A 16. században kibontakozó világkereskedelem sematikus ábrája. Felül a tanitási órán kiadott lap, alul egy ebböl készült tanulói munka.

azokon - néhány kivételtől eltekintve - nem gyakori a domborzat ábrázolása. Hunyadi János törökellenes harcai - például az 1443-1444-es ún. hosszú hadjárat - esetében a tankönyv és az atlasz alapján nehezen értelmezhetö, hogy az egyre keményebb török ellenállás, a tél beállta és a Balkán nehezen járható hágói (SzÁrAy M. - Szabados Gy. 2020) hogyan is hatottak az eseményekre, mivel az említett taneszközökben a Balkánfélszigetről hiányoznak a domborzati elemek, az sík területként van ábrázolva (az Oszmán Birodalom zöld színe is elősegítheti a téves képzet kialakulását). A helyzet hasonló az ipari forradalomnál is, a kapcsolódó térképeken csupán az ásványkincseket tüntették fel, azt viszont nem, hogy az adott területen milyenek a domborzati viszonyok. A domborzati elemek ábrázolása nélkül ugyancsak nehezen érthető meg a középkori bányavárosok elhelyezkedésének oka az Anjou királyaink idején, vagy Széchényi István munkássága a Vaskapu hajózhatóvá tétele kapcsán. Ezek természetesen csak kiragadott 
példák, ám az ilyen és hasonló esetekben jó megoldás lehet, ha a földrajzi és a történelmi atlaszokat egyszerre használjuk a tanórákon (2. ábra). A térképi munka eredményesebbé tehető, ha a tanulók látják a természetföldrajzi és a társadalomföldrajzi összefüggéseket, felismerik, hogy a természetföldrajzi tényezők hogyan nehezítik vagy könnyítik a társadalom müködését, vagy azt, hogy a társadalom hogyan alakítja át a természeti környezetet a saját szükségleteinek kielégítése érdekében.

\section{GAZDASÁGFÖLDRAJZI-GAZDASÁGTÖRTÉNETI JELLEGÜ FEJLESZTÉSI FELADATOK ÉS KULCSFOGALMAK}

A két tantárgy gazdaságföldrajzhoz-gazdaságtörténethez kötődő kerettantervi kulcsfogalmai között alig van olyan, amely mindkét dokumentumban megtalálható (mint pl. infláció, tőke, részvény), ennek ellenére a két tantárgy kapcsolatrendszere jelentős.

A történelem kerettantervben a 8. évfolyam végén található Régiók története címü tematikus egység kiváló terep lehet a történelmi és földrajzi ismeretek szintézisbe hozására. Az évfolyam utolsó négy - hosszmetszeti jellegü - témaköre azt a célt szolgálja, hogy a négy év (5-8. évfolyam) alatt tanultakat áttekintse, a témákat magasabb szinten, integrálva és szintetizálva értelmezze (Kerettanterv az általános iskolák számára, Történelem, 2020). A Régiók története címü témakör témái között szerepel például Magyarország és az Európai Unió (kulcsfogalmak: integráció, euró, Európai Unió),

2. ábra. Hunyadi János törökellenes hadjáratainak vizsgálata középiskolai történelmi és földrajzi atlasz együttes tanulmányozásával (SERES Z. felvétele).
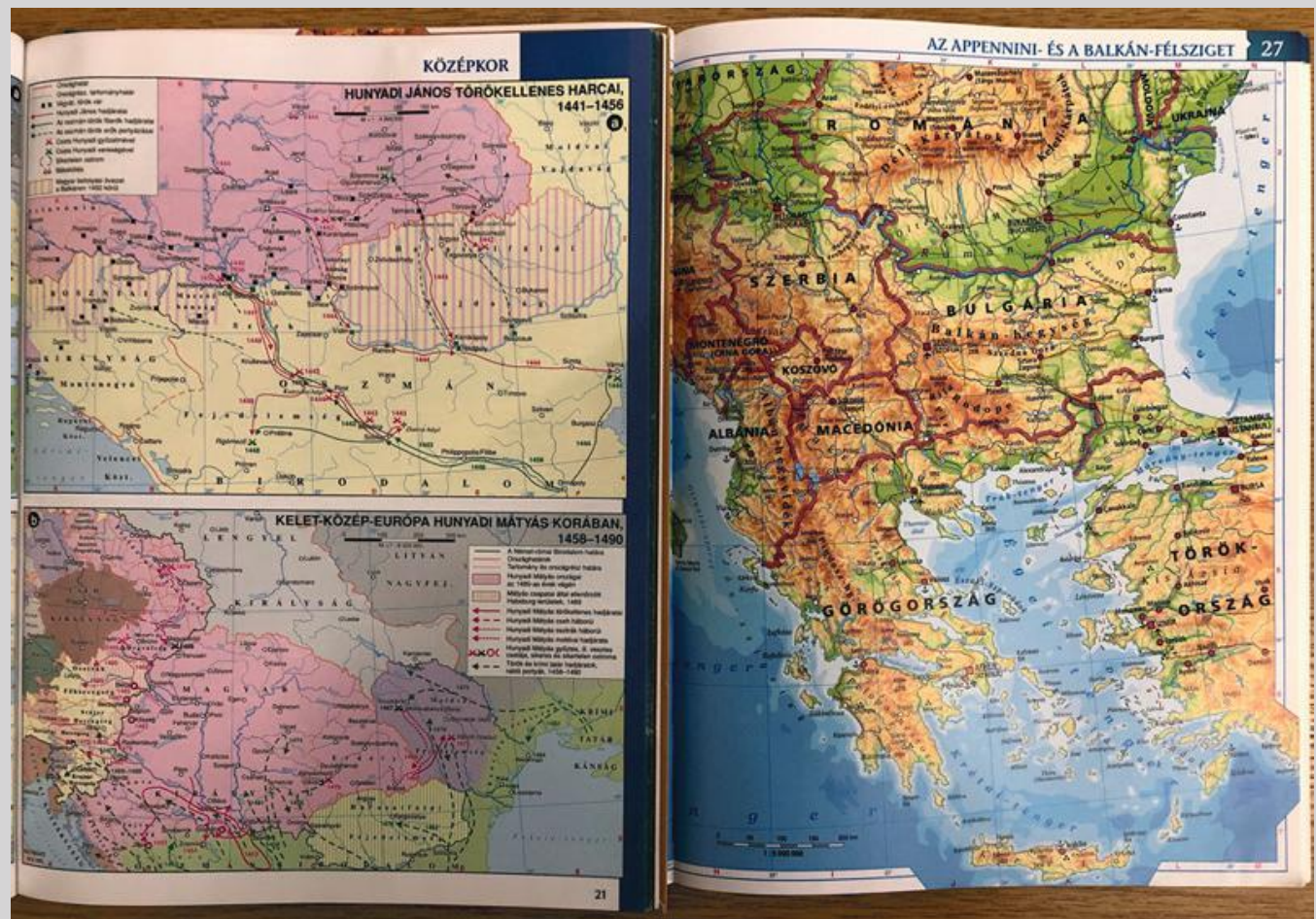
Közép-Európa (kulcsfogalom: visegrádi együttműködés), az A merikai Egyesült Államok (kulcsfogalom: polgárháború), India és Kína (kulcsfogalmak: Nagy fal, hinduizmus, buddhizmus, kasztrendszer) és a Közel-Kelet (kulcsfogalom: Korán). Az előbbi felsorolásból és a hozzájuk kötődő kulcsfogalmakból is látható, hogy a legtöbb esetben igen szoros a kapcsolat a két tantárgy során tanultak között. A 3. ábra megmutatja, hogy a Régiók története címü témakör témái mely, a földrajz kerettantervben megtalálható témakörrel, témákkal dolgoznak fel hasonló ismereteket. Mivel a vizsgált témakör a 8 . évfolyam végén kapott helyet a kerettantervben, így képes lehet szintetizálni nemcsak a történelemórákon, hanem a 7-8. évfolyamon a földrajzórákon tanultakat is, sőt - mivel földrajzból (a történelemhez hasonlóan) valamennyi témakör a későbbi évfolyamokon is előkerül - megágyazhat a középiskolai földrajztanításnak is.

$\mathrm{Az}$ átláthatóság érdekében a témakör témái közül egy általam kiválasztottnak a kapcsolatait mélyebben is bemutatom a 4. ábra segítségével: az Amerikai Egyesült Államok gazdaságával kapcsolatos témák a két tantárgy esetében négyszer is előkerülnek a vizsgált négy évfolyamon. Ezek ugyan nem egymással párhuzamosan, hanem egymástól függetlenül, más-más alkalommal jelennek meg, ám javasolt az egyes órákon vissza, illetve elöre utalni, hogy a tanulók lássák a tantárgyak közötti kapcsolódásokat,

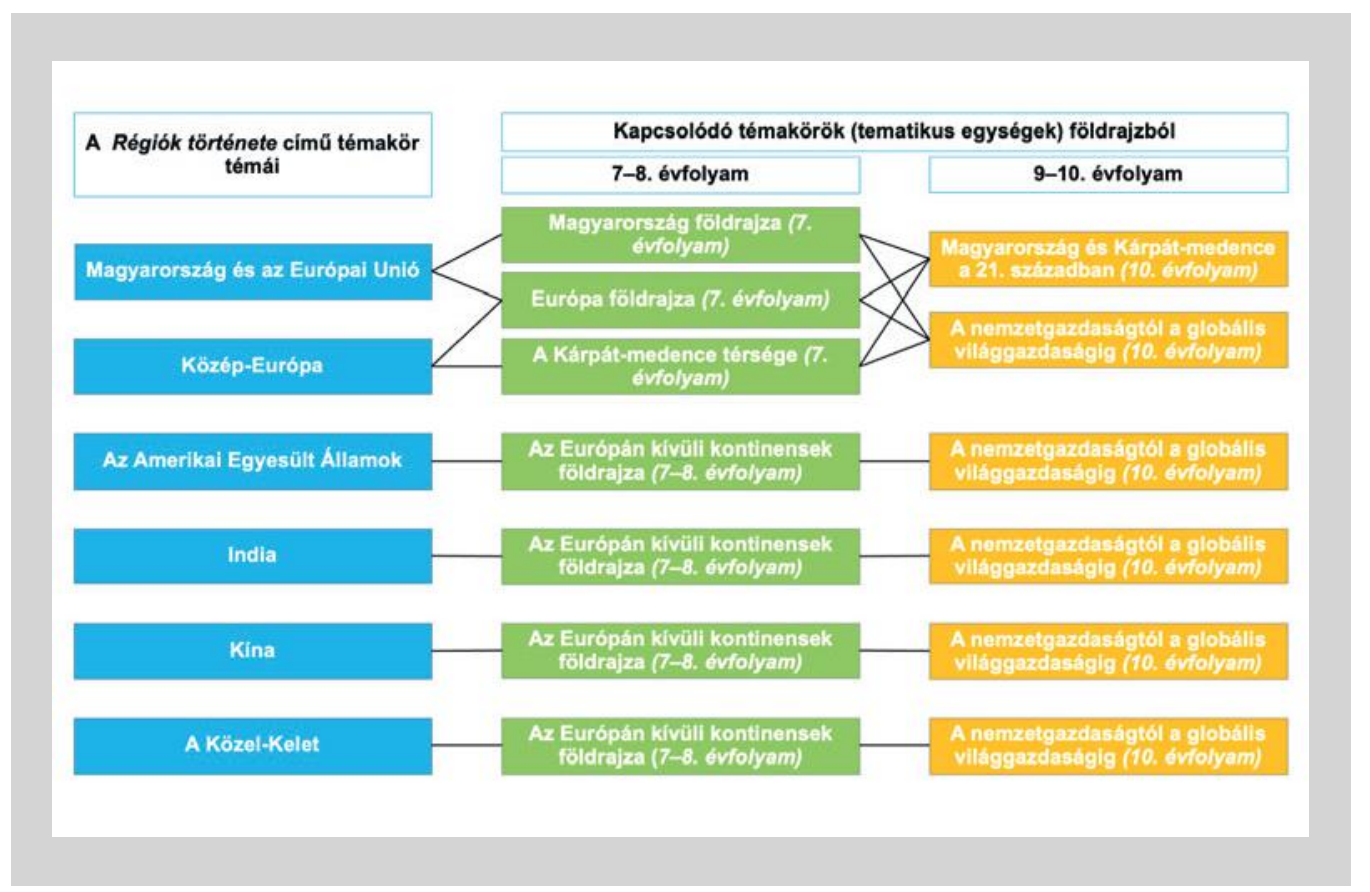

3. ábra. A Régiók története címü történelem témakör témái és azok kapcsolódása a földrajz kerettanterv nagy témaköreihez, tematikus egységeihez (szerk. SERES Z.) 
összefüggéseket. Célszerü elkerülni, csökkenteni az ismétléseket, hiszen nem az a célunk, hogy bizonyos ismereteket újra és újra megtanítsuk a tanulóknak, hanem hogy mélyítsük, szintetizáljuk a korábban tanultakat. Éppen ezért különösen fontos a kooperáció a tantárgyakat tanító pedagógusok között; a helyi tantervek elkészítésénél érdemes tisztáznunk, hogy ki, milyen ismereteket, milyen célokkal és hogyan (pl. mely készségeket fejlesztve, melyik kompetenciaterületre helyezve a hangsúlyt) dolgoz fel a tanulókkal. Mindezzel könnyíthető a tanulók és a pedagógusok munkája is: az előbbiek motivációja megmarad, míg az utóbbiak tudatosabban építhetnek a tanulók más tanórán megismert ismereteire, fejlesztett készségeire. Fontos hangsúlyozni, hogy a pedagógusok közötti együttműködések, tapasztalatcserék pozitívan befolyásolják a tanulók teljesítményét; az oktatás mint kollektív vállalkozás a szakszerü együttmüködések révén növeli a tanulói teljesítményeket, valamint a tanári professzionalizmust (HARGREAVES, A. - FULLAN, M. 2012, idézi FehérvÁri A. et al. 2018).

A két tantárgy számtalan helyen kapcsolódik össze a gazdaságföldrajzi-gazdaságtörténeti ismeretek tekintetében. Ilyen gócpontok lehetnek - a teljesség igénye nélkül

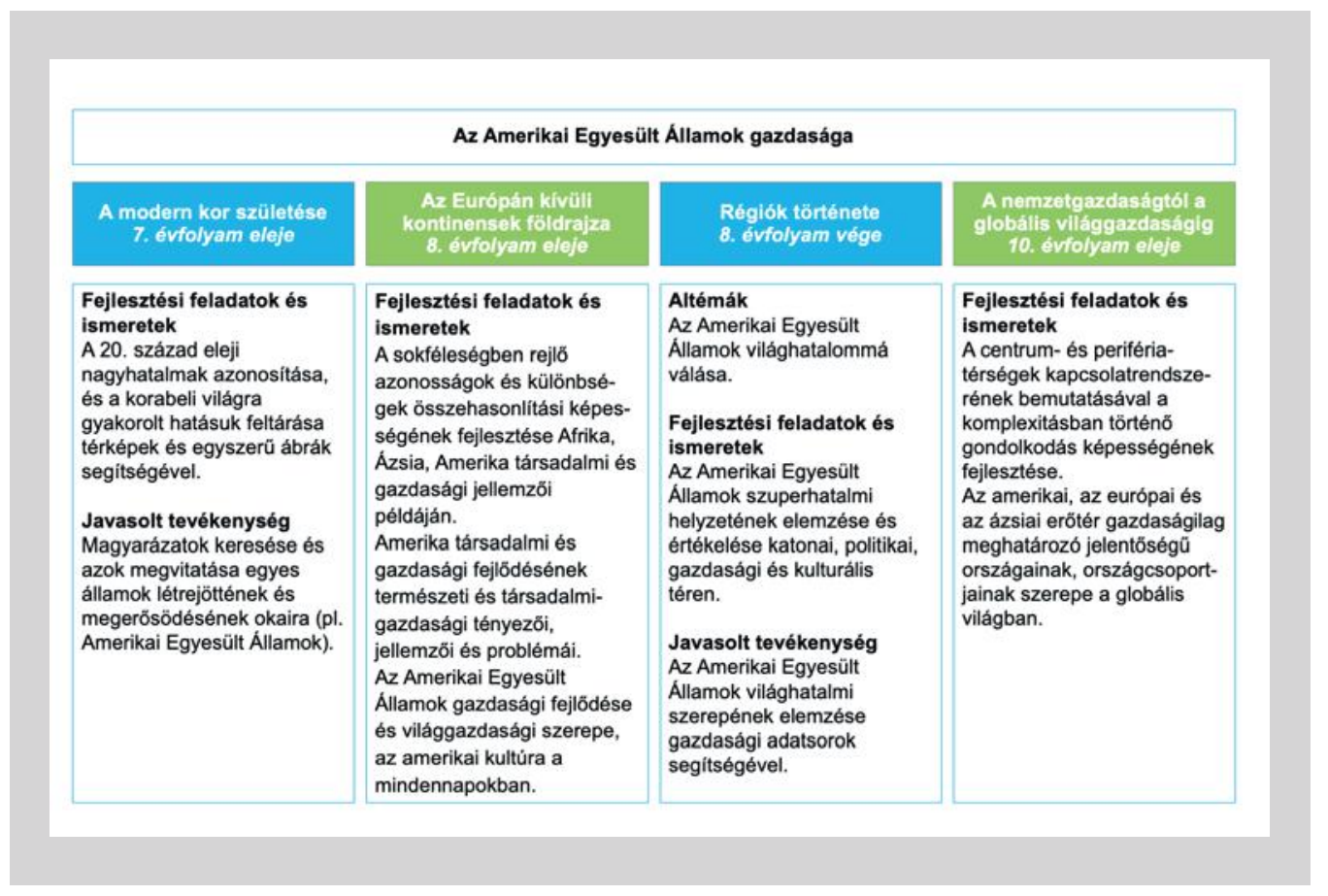

4. ábra. Az Amerikai Egyesült Államok gazdaságával kapcsolatos témakörök és témák a földrajz-és a történelem kerettantervekben (a Kerettanterv az általános iskolák a gimnáziumok számára - Földrajz, Történelem, 2020 alapján szerk. SERES Z.) 
- Magyarország szovjetizálása - 8. évfolyam (pl. államosítás, tervgazdaság), A forradalomtól az ezredfordulóig - 7. évfolyam (privatizáció, rendszerváltoztatás), A kora újkor (a földrajzi felfedezések) - 10. évfolyam (pl. gyarmat, világkereskedelem, bank), Az iparosodás kora - 10. évfolyam (pl. ipari forradalom, tömegtermelés). Természetesen ezek csak azok a témakörök, ahol igen sok lehetőség van a két tantárgy kapcsolatainak kidomborítására, az egyik vagy a másik tantárgy során tanultak felidézésére és rendszerezésére, ám szinte alig van olyan témakör vagy téma, amelyen belül ne lenne lehetőség ezekre.

\section{TÁRSADALOMFÖLDRAJZI-TÁRSADALOMTÖRTÉNETI JELLEGÜ FEJLESZTÉSI FELADATOK ÉS KULCSFOGALMAK}

Történelemből a 8. évfolyam végén a Népesedés és társadalom címü tematikus egységen belül számos társadalomföldrajzi-társadalomtörténeti altéma kerül előtérbe. A témakör esetében a cél ugyanaz, mint az előbbiekben bemutatott Régiók története címü témakörnél (a korábban tanultak áttekintése, azok magasabb szinten történő értelmezése), s úgy, mint ott, itt is sokrétü a kapcsolat a két tantárgy között (pl. a népességnövekedés korlátai, népességrobbanás, migráció, globalizáció, modern kori demográfiai folyamatok). A témakör részletes elemzésétől most eltekintek, helyette olyan témaköröket, témákat mutatok be, ahol - ehhez hasonlóan - építenünk kell az egyik vagy másik tantárgy során tanultakra.

A 9. évfolyam vége felé közeledve az Átalakuló települések, eltérö demográfiai problémák a 21. században (7 tanóra) című földrajz kerettantervi témakör jó lehetőség a két tantárgy összekapcsolására (5. ábra), különösen akkor, ha kihasználjuk a történelem kerettanterv által előírt mélységelvű tanórákat (tanévente 6-7 tanóra) is. Ezek olyan - legalább 70\%-ukban magyar történelemmel kapcsolatos - témák, amelyeket a szaktanár jelöl ki a helyi tanterv alapján, és amelyek lehetőséget adnak az adott téma részletesebb ismeretekkel, többféle megközelítési móddal és tevékenységgel történő feldolgozására (Kerettanterv a gimnáziumok számára, Történelem, 2020). Az említett témakör nem elözmények nélküli, hiszen mind a földrajz- (pl. Magyarország földrajza, Európa földrajza), mind a történelem kerettantervben (pl. az imént említett Népesedés és társadalom címü témakör) - ha csak szétszórva is és nem egy egységes témakörön belül - szerepelnek ezzel kapcsolatos kulcsfogalmak, ismeretek (pl. nemzeti kisebbség, elöregedő társadalom, agglomeráció). Célravezető a 9. évfolyamon a történelem tantárgy mélységelvü óráit népesség- és településföldrajzra fordítani és a témát a földrajz tantárgy kapcsolódó témakörével egyidőben feldolgozni. Mivel a témák hozzávetőlegesen a tanév végén helyezkednek el, így a történelemórákon sort keríthetünk egy hosszmetszeti, az egész éves tananyagot szintetizáló témakör megvalósítására, a földrajzórákon a korábban 


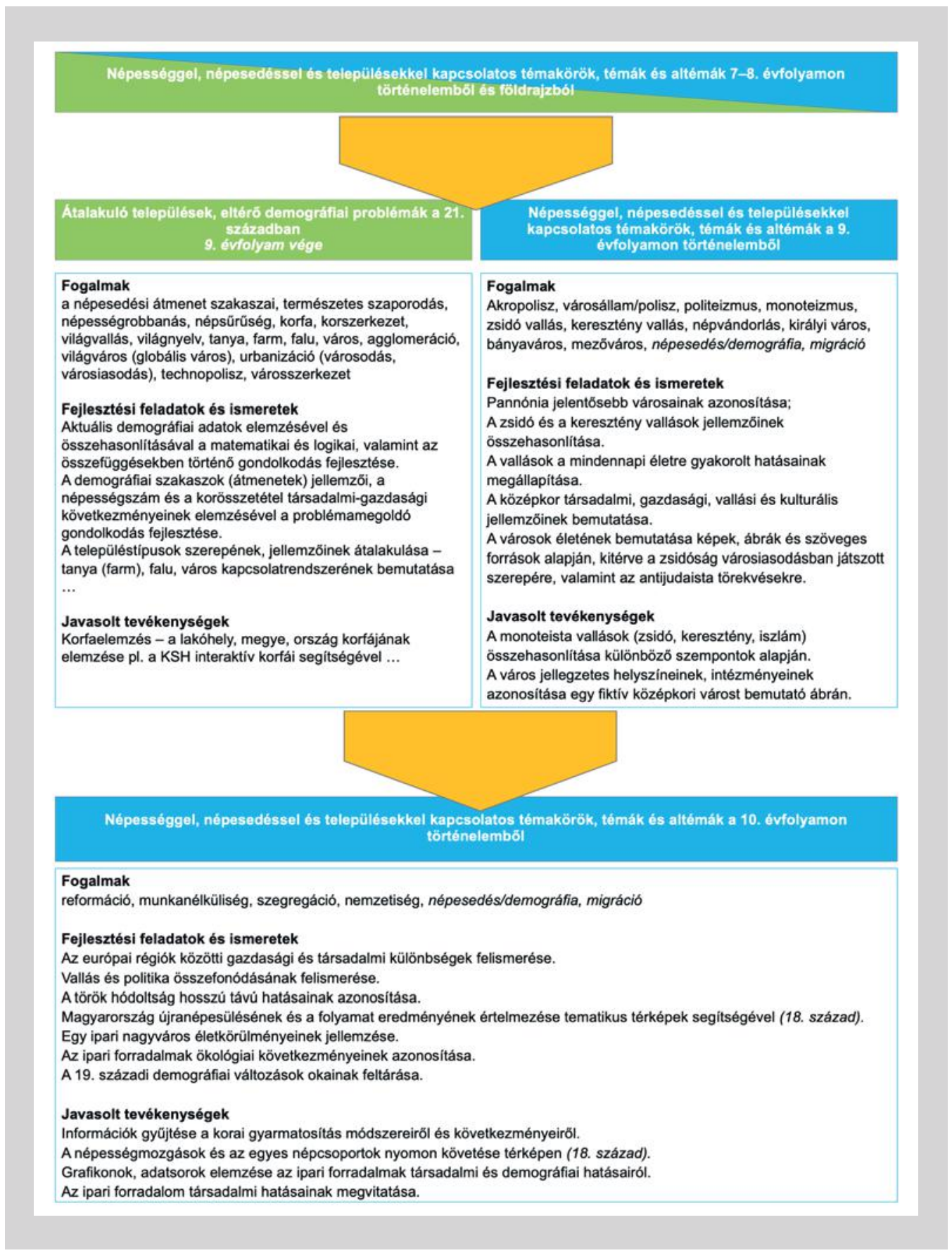

5. ábra. Népességgel, népesedéssel és településekkel kapcsolatos témakörök, témák és altémák a 9-10. évfolyamon (Kerettanterv az általános iskolák és a gimnáziumok számára - Földrajz, Történelem, 2020 alapján szerk. SERES Z.) 
(is) tanult ismeretek magasabb szinten történő tanulásával párhuzamosan. Mindezt érdemes nem egymástól függetlenül, hanem egymást segítve megvalósítani (hiszen attól, hogy két különböző tanórán párhuzamosan tanulnak a tanulók hasonló ismereteket, még nem feltétlenül tudják összekapcsolni azokat egymással), erre jó megoldás lehet egy téma- vagy projektnap. Ennek keretein belül áttekinthetjük a témakört az őskortól kezdve napjainkig, megvizsgálhatjuk az ókori, illetve középkori települések lenyomatait a mai városok esetében (pl. Athén, Róma vagy Sopron példáján), kitérhetünk a korai településfejlődést segítő természeti adottságokra (pl. dombtető, folyótorkolat), vagy a népességgel, népesedéssel összefüggő korábbi (pl. pestisjárványok, tatárjárás) és napjainkbeli (pl. túlnépesedés, elöregedés) problémákra. A 9. évfolyam végén is - hasonlóan a 8. évfolyam végéhez - érdemes tehát egy integrált elvek alapján megvalósuló áttekintést beillesztenünk, hiszen egyrészt átismételjük és megerősítjük a korábban tanultakat, másrészt magasabb szinten tanuljuk és szintetizáljuk is egymással azokat, harmadrészt pedig előkészítjük a magasabb évfolyamok földrajzi-történelmi jellegű témáit.

Utóbbi igen fontos, hiszen - ahogyan azt az 5. ábra is szemlélteti - a magasabb évfolyamokon is igen széles a két tantárgy kapcsolatrendszere, amelyre célszerü tudatosan építkeznünk. Földrajzórán Latin-Amerika földrajzánál (A nemzetgazdaságtól a globális világgazdaságig - A világgazdaság erőterei témakörön belül - 10. évfolyam) ahhoz, hogy megértsük a jelen társadalmi-gazdasági folyamatait, elengedhetetlen ismernünk a földrajzi felfedezések hatásait, a gyarmatosítás napjainkban is érezhető társadalmi (pl. az emberfajták nagyfokú keveredése) és gazdasági (pl. torz gazdasági szerkezet) következményeit (vö. CzIrfusz M. 2020). Az ipari forradalom esetében történelemórán ugyancsak fontos a demográfiai robbanás vagy az urbanizáció megértéséhez mindaz, amit földrajzórán tanulhatunk. Lényeges, hogy következetesen használjuk azokat a fogalmakat (pl. városodás, városiasodás, népességmozgás), amelyekkel a tanulók földrajzórán is találkoznak, és ezek ugyanazt jelentsék mindkét tantárgy esetében. A következetes fogalomhasználat valamennyi témakör esetében rendkívül fontos, így például hazánk 18. századi újjáépítésénél is (pl. nemzetiség, soknemzetiségü ország).

\section{KÖVETKEZTETÉSEK}

A tanulmányban áttekintettem a földrajz és a történelem tantárgy kapcsolatát, majd megvizsgáltam a tantervi szabályozókat, különös tekintettel a kerettantervekre. Ezek alapján megállapítható, hogy a két tantárgynak - a kezdetektől fogva - rendkívül szoros a kapcsolata, elsődlegesen a gazdaság- és társadalomföldrajzi témák vonatkozásában, de a topográfiai-téri jellegű témák, fejlesztési célok esetében is. Látható, hogy a vizsgált tartalmak átszövik mindkét tantárgyat és búvópatakként bukkannak elő valamennyi 
tematikus egység esetében, azok egymástól nem különíthetők el élesen (bár ez utóbbi nem is cél). A két tantárgy esetében fellelhetők olyan csomópontok is (pl. a földrajzi felfedezések, az ipari forradalmak, világgazdasági folyamatok), ahol egyértelmüen kimutatható a két tantárgy tartalma közötti rendkívül szoros kapcsolat, és amelyek esetében igen nehezen érthető meg a tananyag a másik tantárgy keretében tanultak nélkül. Azonban a sikeres tantárgyi integrációt és az ismeretek szintézisbe hozását nehezíti a két tantárgy (egymáshoz és a földrajz esetében saját magához képest is) logikátlan időbeli elhelyezkedése, a tananyagelrendezés és a rendelkezésre álló szűk időkeret, amely problémák kiküszöbölésében - helyi, intézményi szinten - a pedagógusok járhatnak elől.

A tanulmányban a kerettantervek alapján, három nagyobb részterület mentén bemutattam néhány lehetséges kapcsolódási pontot a két tantárgy között, mindegyik esetben felvázolva egy-két, tanításban is használható ötletet, javaslatot. A célom nem a kapcsolatok teljes körü bemutatása volt, hanem hogy elindítsam a gondolkodást az általam hozott példák segítségével, valamint felhívjam a figyelmet arra, hogy a szaktanárok együttműködésével eredményesebbé tehető a tanulás. Mindenképpen érdemes nagy figyelmet fordítani a tantervi szabályozókra és felhasználni az azokban rejlő lehetőségeket (pl. mélységelvű órák), azok alapján pedig a kollégákkal együttműködve kialakítani a helyi tanterveket, amihez nagy segítséget jelenthetnek a tanulmányban található táblázatok és áttekintő ábrák.

\section{IRODALOM}

BAbÁly Bernadett - KÁrpáti Andrea (2015): A téri képességek vizsgálata papír alapú és online tesztekkel. - Magyar Pedagógia 115. 2. pp. 67-92. https://doi.org/10.17670/MPed.2015.2.67

BÁNkUti Zsuzsa - Csorba F. LÁsZló - Kor PICs Zsolt - ÜtőNÉ VISI Judit (2011): Tantárgyközi kapcsolatok. - In: Bánkuti Zsuzsa - Csorba F. László (szerk.): Átmenet a tantárgyak között. A természettudományos tantárgyak megújításának lehetőségei. Oktatáskutató és Fejlesztő Intézet, Budapest. 265 p. http://mek.oszk.hu/13500/13598/13598.pdf [utolsó megtekintés: 2021. 06. 14.]

Botos Réka - Paveszka Dóra (2020): „Egymás szemében... - avagy egy fejlesztőpedagógus és egy magyartanár együttmüködése az online és offline térben”. - Új Pedagógiai Szemle 70. 7-8. pp. 68-75. https://epa.oszk.hu/00000/00035/00229/pdf/EPA00035_upsz_2020_07-08_068-075.pdf [utolsó megtekintés: 2021. 06. 29.]

Czirfusz MÁrton (2020): Népesség- és településföldrajz a gimnáziumban - szemléletváltási lehetőségek. - GeoMetodika 4. 3. pp. 49-59.

Czirfusz MÁrton - Gyapay Borbála (2018): Megismerés a tanulásban és a tudományban. A gazdaságföldrajz tanításának módszertani kérdései. - GeoMetodika 2. 3. pp. 5-21. https://doi.org/10.26888/ GEOMET.2018.2.3.1

FARSANG ANDREA - ÜTŐNÉ VISI JUdit (2020): Új kihívások a földrajzoktatásban - Nemzeti alaptanterv és kerettanterv 2020 - GeoMetodika 4. 2. pp. 33-46. 
Fehérvári Anikó - Széll Krisztián - Paksi Borbála - Zsolnai Anikó (2018): Szervezeti jellemzők és iskolai eredményesség. - In: Fehérvári Anikó (szerk.): A Borsszem Jankótól Bolognáig. Neveléstudományi Tanulmányok, ELTE PPK - L’Harmattan Kiadó, Budapest. pp. 77-94.

KAPOSI József (2020): A hazai történelemoktatás dilemmái. - Történelemtanítás online történelemdidaktikai folyóirat 11. 1-2. http://www.folyoirat.tortenelemtanitas.hu/2020/05/kaposi-jozsef-a-hazai-tortenelemoktatas-dilemmai-11-01-03/ [utolsó megtekintés: 2021. 06. 14.]

Kerber Zoltán (2009): A tantárgyközi oktatás helyzete. - Oktatáskutató és Fejlesztő Intézet, Budapest. https://ofi.oh.gov.hu/tantargykozi-oktatas-helyzete [utolsó megtekintés: 2021. 07.01.)

KoJAnITz LÁszLÓ (szerk., 2018): A történelemtanítás megújítása. Kerekasztal-beszélgetés az EKE-OFI-ban. - Történelemtanítás online történelemdidaktikai folyóirat 9. 3-4. http://www.folyoirat.tortenelemtanitas.hu/2018/11/a-tortenelemtanitas-megujitasa-09-03-04/ [utolsó megtekintés: 2021. 06. 14.]

MaKÁdi Mariann (2020a): A földrajztanítás szakmódszertani alapjai. Mielőtt tanítani kezdene... ELTE TTK FFI Földrajz szakmódszertani csoport, Budapest. 179 p.

Makádi Mariann (2020b): A földrajztanítás szakmódszertani alapjai. Hogy tudatosan végezze... - ELTE TTK FFI Földrajz szakmódszertani csoport, Budapest. 233 p.

Probáld Ferenc (2017): A földrajz helyzete tanterveinkben: múlt, jelen, jövő. GeoMetodika 1. 1. pp. 7-20. https://doi.org/10.26888/GEOMET.2017.1.1.1

Seres Zoltán (2021): Majd akkor megyünk át a hídon... - A 2020-ban megjelent tantervi szabályozók hatása a földrajz tantárgyra és a természettudományokra. - Iskolakultúra 31. 5. pp. 108-124.

SzÁRAy Miklós (2010): A térkép szerepe és elemzése a történelemórán. - Történelemtanítás online történelemdidaktikai folyóirat 1. 2. http://www.folyoirat.tortenelemtanitas.hu/2010/05/szaray-miklos-a-terkep-szerepe-es-elemzese-a-tortenelemoran/ [utolsó megtekintés: 2021. 05. 27.]

SzÁray Miklós - Szabados György (2020): Történelem 9. Tankönyv. - Oktatási Hivatal, Budapest. 184 p. https://www.tankonyvkatalogus.hu/pdf/OH-TOR09TB__teljes.pdf [utolsó megtekintés: 2021. 06. 14.]

Teperics Károly - Sáriné Gál Erzsébet - Németh Gábor - Sütő László - Homoki Erika (2015): Földrajztanítás - válogatott módszertani fejezetek. - Debreceni Egyetem Kiadó, Debrecen. 245 p.

ÜTŐNÉ VISI JUDIT (2009): A földrajz tantárgy helyzete és fejlesztési feladatai. https://ofi.oh.gov.hu/foldrajz-tantargy-helyzete-es-fejlesztesi-feladatai [utolsó megtekintés: 2021. 05. 27.]

A vizsgakövetelményekhez kapcsolódó topográfiai fogalmak a közép- és emelt szintű vizsgákhoz. Földrajz. - https://dload-oktatas.educatio.hu/erettsegi/nyilvanos_anyagok_2021tavasz/foldrajz_topografiai_ fogalmak_2021maj.pdf [utolsó megtekintés: 2021.07.01.]

Földrajzi atlasz középiskolásoknak (2021). - Oktatási Hivatal, Budapest. 84 p. https://www.tankonyvkatalogus.hu/pdf/FI-506010903_2__teljes.pdf

Kerettanterv az általános iskola 5-8. évfolyama számára, Földrajz. - https://www.oktatas.hu/kozneveles/ kerettantervek/2020_nat/kerettanterv_alt_isk_5_8

Kerettanterv gimnáziumok 9-12. évfolyama számára, Földrajz. -https://www.oktatas.hu/kozneveles/ kerettantervek/2020_nat/kerettanterv_gimn_9_12_evf

Kerettanterv az általános iskola 5-8. évfolyama számára, Természettudomány. - https://www.oktatas.hu/ kozneveles/kerettantervek/2020_nat/kerettanterv_alt_isk_5_8

Kerettanterv az általános iskola 5-8. évfolyama számára, Történelem. -https://www.oktatas.hu/ kozneveles/kerettantervek/2020_nat/kerettanterv_alt_isk_5_8 
Kerettanterv a gimnáziumok 9-12. évfolyama számára, Történelem. -https://www.oktatas.hu/kozneveles/ kerettantervek/2020_nat/kerettanterv_gimn_9_12_evf

Nemzeti alaptanterv 2020: 5/2020. (I. 31.) Korm. rendelet A Nemzeti alaptanterv kiadásáról, bevezetéséről és alkalmazásáról szóló 110/2012. (VI. 4.) Korm. rendelet módosításáról. - Magyar Közlöny 2020. 17.pp. 290-446. https://magyarkozlony.hu/dokumentumok/3288b6548a740b9c8daf918a399a0bed1985db0f/ megtekintes

Történelmi atlasz középiskolásoknak (2017). - Oktatási Hivatal (Oktatáskutató és Fejlesztő Intézet), Budapest. 90 p. https://www.tankonyvkatalogus.hu/pdf/FI-504010903_2_teljes.pdf

Új laptárs: GeoMetodika. - Történelemtanítás online történelemdidaktikai folyóirat 8. 1-2. https://www. folyoirat.tortenelemtanitas.hu/wp-content/uploads/2017/10/08_01_17_geometodika.pdf [utolsó megtekintés: 2021. 05. 27.] 